\title{
Influence of feeding level on the population of C-terminal-gastrin-immunoreactive cells in the digestive tract of young Clarias gariepinus (Burchell 1822)
}

\author{
J. H. BOON 1 , J. H. W. M. ROMBOUTS 2 , G. H. R. BOOMS ${ }^{1,2}$ \& M. A. M.
} MACHIELS ${ }^{1}$

1 Department of Fish Culture and Fisheries, Wageningen Agricultural University, P.O.Box 338, $6700 \mathrm{AH}$ Wageningen, Netherlands

2 Department of Experimental Cell Biology and Animal Morphology, Wageningen Agricultural University, P.O.Box 338, $6700 \mathrm{AH}$ Wageningen, Netherlands

Received 22 August 1989; accepted 13 November 1989

\begin{abstract}
C-terminal-gastrin-immunoreactive cells, probably representing cholecystokinin (CCK)cells, were predominantly found in the first flexure of the anterior part of the intestine of young African catfish (Clarias gariepinus). Gastrin-containing cells could not be demonstrated in the stomaç using the same technique and antibodies, suggesting the presence of different $\mathrm{C}$ terminus of gastrin in this species compared with higher vertebrates. The number of CCK-like cells did hardly change with time in fish receiving a low feeding level. However, in fish receiving a high feeding level the number of CCK-cells increased from the sixth week on and was significantly higher than the number in fish with the low feeding level at the age of 8 weeks. The significance of this result is discussed.
\end{abstract}

Keywords: digestive tract, C-t-gastrin-immunoreactive cell, immunohistochemistry, hormones, feeding level, Clarias gariepinus

\section{Introduction}

Although the digestive tract of Clarias gariepinus is well described by Stroband \& Kroon (1981), no data are available on the gut endocrine system of this species. This is in contract to what is known of this system in other fish species. Recently, immunocytochemical studies, using antisera against mammalian hormones, demonstrated the presence of several mammalian hormones in the digestive tract of fish which have no stomach (Rombout et al., 1986). With the same technique most mammalian hormones were detected in the digestive tract of fish which do have a stomach (Abad et al., 1987). Gastrin and cholecystokinin(CCK)-like hormones, demonstrated with antisera against $\mathrm{C}$-terminal (C-t) gastrin, appeared to be present 
in all fish species investigated. Hormones are very important for the release of acid, enzymes and bile into the digestive system of mammals (Modlin et al., 1981) and fish (van Noorden et al., 1980) and for the control of gut motility in fish (Jonsson et al., 1987).

The African catfish is able to digest infrequent and irregular meals effectively. This is caused by a relatively rapid secretion of digestive enzymes after feeding (Uys et al., 1987). The question rose whether there is a relationship between the number of hormoneproducing cells in the digestive tract, the quantity of digestive enzymes and feeding level to optimize the digestive capacity. The answer could be used for the development of an improved feeding regime in the culture of the African catfish to obtain an improved growth. Therefore, a study into this relationship was initiated. As a part of it the presence, number and the localization of C-t-gastrinimmunoreactive cells in the digestive tract of C.gariepinus at different feeding levels have been investigated.

\section{Material and methods}

Fish

Larvae of C.gariepinus were obtained by artificial reproduction (Hogendoorn \& Vismans, 1980) and fed nauplii of Artemia during the first 9 days after hatching. Ultimately a commercial trout feed was given. Seven days after hatching, the larvae were divided at random over two aquaria, each aquarium containing 300 fish. From day 10 after hatching onwards, a commercial trout feed was given. On day 14 after hatching, each aquarium was allotted to a high or a low feeding level. Mortality was recorded daily.

\section{Feed and feeding levels}

Direct after hatching of C.gariepinus Instar I nauplii of Artemia were fed until satiation. From day 10 after hatching, Scharflinger conveyor belt feeders supplied food continuously between 09.00 and $24.00 \mathrm{~h}$. Different crumb sizes were used for different sizes of fish. The food composition as given by the manufacturer is listed in Table 1 . Food rations from day 14 were 9 and $27 \%$ of fresh body weight per day at the low and high feeding level, respectively. The low level is comparable to the level defined by Hogendoorn et al. (1983) as physiological optimal, providing for the minimal feed conversion. The high feeding level is considered to be ad libitum feeding and may therefore be defined as the level giving maximum growth.

\section{Experimental conditions}

The two 701 aquaria in which the fish were kept were both part of the same recirculation system with a total volume of $2380 \mathrm{l}$. Ammonia and nitrite values were kept below $0.5 \mathrm{mg} \mathrm{l}^{-1}$ and nitrate below $100 \mathrm{mg} \mathrm{l}^{-1}$. Water temperature was $25^{\circ} \mathrm{C}$. Dissolved oxygen ranged from 83 to $98 \%$ saturation. The $\mathrm{pH}$ fluctuated between 6.50 and 7.65 . 
Table 1. Crumb sizes used for different weight ranges of fish, and feed composition.

\begin{tabular}{lc}
\hline Weight range $(\mathrm{g})$ & Mean crumb size $(\mathrm{mm})$ \\
& \\
$0.05-0.5$ & 0.5 \\
$0.5-1.0$ & 1.2 \\
1.0 -final weight & 1.7 \\
& \\
Composition of the commercial diet used & \\
& \\
Dry matter $(\%)$ & 90.5 \\
Crude protein $(\%)$ & 51.0 \\
Crude fat $(\%)$ & 9.0 \\
Ash $(\%)$ & 10.5 \\
Fibre $(\%)$ & 1.5 \\
Carbohydrates $(\%)$ & 18.5 \\
Vitamin A (IE $\left.\mathrm{kg}^{-1}\right)$ & 20.000 \\
Vitamin $\mathrm{D}_{3}\left(\mathrm{IE} \mathrm{kg}^{-1}\right)$ & 2.000 \\
Vitamin $\mathrm{E} \mathrm{(mg} \mathrm{kg-1)}$ & 50 \\
Vitamin C (mg kg-1) & 1.000 \\
\hline
\end{tabular}

\section{Experimental procedure}

The experiment lasted 8 weeks. Once a week, 10 randomly chosen fish were sampled and weighed to determine the average growth curve of the fish in relation to the respective feeding levels. Four fish out of the samples (on day $21,28,35,42,49$ and 56) were used for immunohistochemistry.

\section{Immunohistochemistry}

Sampled fish were killed by decapitation and fixed in toto in Bouin's fluid (Romeis, 1968). From fish weighing more than $0.5 \mathrm{~g}$ the gastro-intestinal tract was dissected and embedded, while smaller fish were embedded in toto in Paraplast Plus (Sherwood). Tissue was serially sectioned at $5 \mu \mathrm{m}$ and mounted on poly-L-lysine (MW: 350 000; Sigma)-coated slides. After dewaxing and rehydratation, sections were rinsed several times in $0.01 \mathrm{M}$ phosphate-buffered $0.15 \mathrm{M}$ saline (PBS; $\mathrm{pH}$ 7.2). The peroxidase-anti-peroxidase (PAP) method (Sternberger,1979) was used to demonstrate gastrin and CCK-like peptides in gut endocrine cells. In the first step, rabbit serum ( 1 : 3000; provided by Prof. Dr Bosman, Leiden/Maastricht, Netherlands) was used; it was raised against synthetic human gastrin and was demonstrated to react specifically with the C-terminal part of the gastrin and CCK (Rombout et al., 1986; Abad et al., 1987). A swine-anti-rabbit serum (1:50; Dakopatts, Denmark) and a rabbit PAP-complex (1:100; Dakopatts) was used in the second and third steps, respectively. All necessary controls (Grube, 1980; Rombout et al., 1986; Scopsi et al., 1986) were carried out to avoid non-specific binding of antibodies to anionic or cationic constituents of endocrine cells. Quantative evaluations were made on 
cross sections of 4 specimens per sample date and feeding level. C-t-gastrinimmunoreactive cells were counted in the anterior part of the gut, just behind the stomach, where most of these cells are located. The number of immunoreactive cells was calculated per 1000 epithelial cells using a quadrangle of $0.5 \times 0.5 \mathrm{~mm}$ with 100 squares of $0.05 \times 0.05 \mathrm{~mm}$ at a magnification of $200 \times$. All immunoreactive cells in the quadrangle were counted, whereas epithelial cells were calculated based on the counting of 10 squares on the diagonal. This procedure was repeated 2-5 times, depending on the fish size.

\section{Statistics}

Differences in growth and number of C-t-gastrin-immunoreactive cells between feeding levels on the same dates were analysed using the Student's $T$ test. The relationship between the number of C-t-gastrin-immunoreactive cells and growth and the feeding level were analysed using Anova (Snedecor \& Cochran,1976).

\section{Results}

Both feeding levels declined during the experimental period as illustrated in Figure 1. The mean growth of this fish is given in Figure 2. The high feeding level fish (HFL) grow faster than the low feeding level fish (LFL) from day 35 onwards $(P<0.01)$. Between day 42 and day 49 a peak in the mortality of $15 \%$ occurs in the HFL fish, while the mortality of the LFL was $1 \%$ during the same period. This mortality was caused by the ruptured intestine syndrome (RIS) (Boon et al., 1987).

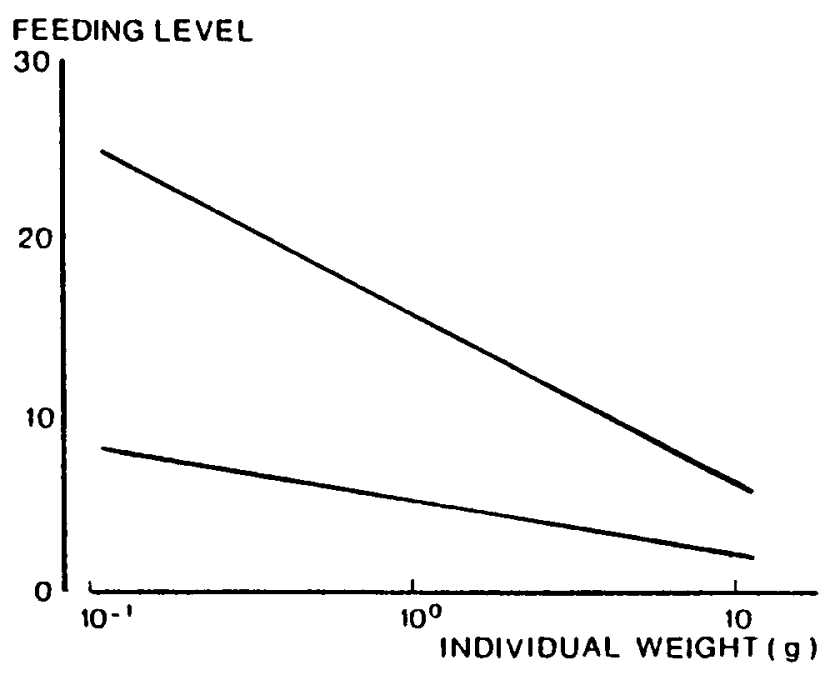

Fig. 1. Clarias gariepinus. Relationship between feeding level ( $\%$ of fresh body weight per day) and mean fresh body weight $(\mathrm{g})$. 


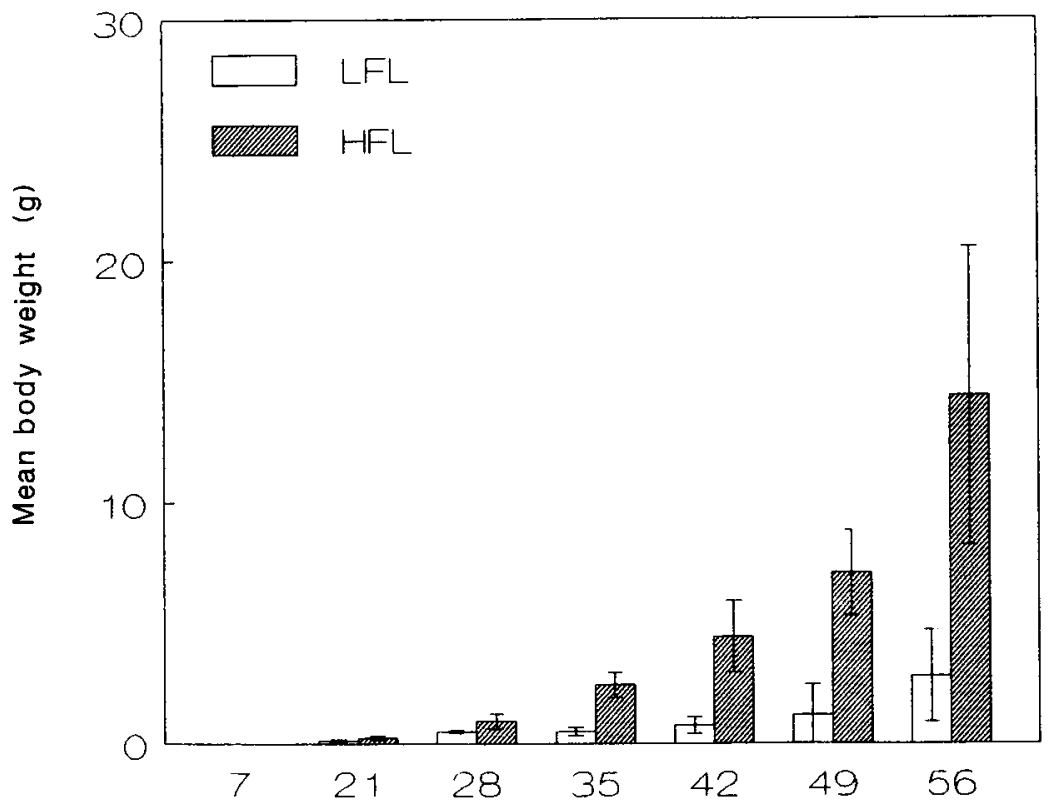

Time (d)

Fig. 2. Clarias gariepinus. Mean fresh body weight $(+/-\mathrm{SD})(n=10)$ per feeding level versus time. LFL = low feeding level, HFL = high feeding level.

Many C-t-gastrin-immunoreactive cells were found in the anterior part of the intestine and some were present in the middle part of the gut, but they were not found in the stomach of C.gariepinus (Fig.3a-c). Most of the immunoreactive cells appeared to be present in the first flexure of the gut and seemed to be of the open type, i.e. having a secretory granule containing base and a long narrow extension towards the intestinal lumen (Fig.4). The number of C-t-gastrin-immunoreactive cells per 1000 epithelial cells related to age and feeding level is shown in Figure 5. The difference in cell numbers between the feeding levels is significant on day $56(P<0.05)$.

\section{Discussion}

The growth of the fish of both feeding levels was comparable to those given by Hogendoorn et al. (1983). This is an indication that the digestive activity of the digestive tract was normal. C-t-gastrin-immunoreactive cells were predominantly found in the anterior part of the intestine of Clarias gariepinus, whereas they were absent in the stomach. A similar distribution pattern was found in Sparus auratus by Abad et al. (1987), using different antisera (Langer et al., 1979; Holmgren et al., 1982). On the other hand, several authors described the presence of gastrinimmunoreactive cells in the stomach of some teleost species (Larsson \& Reh- 

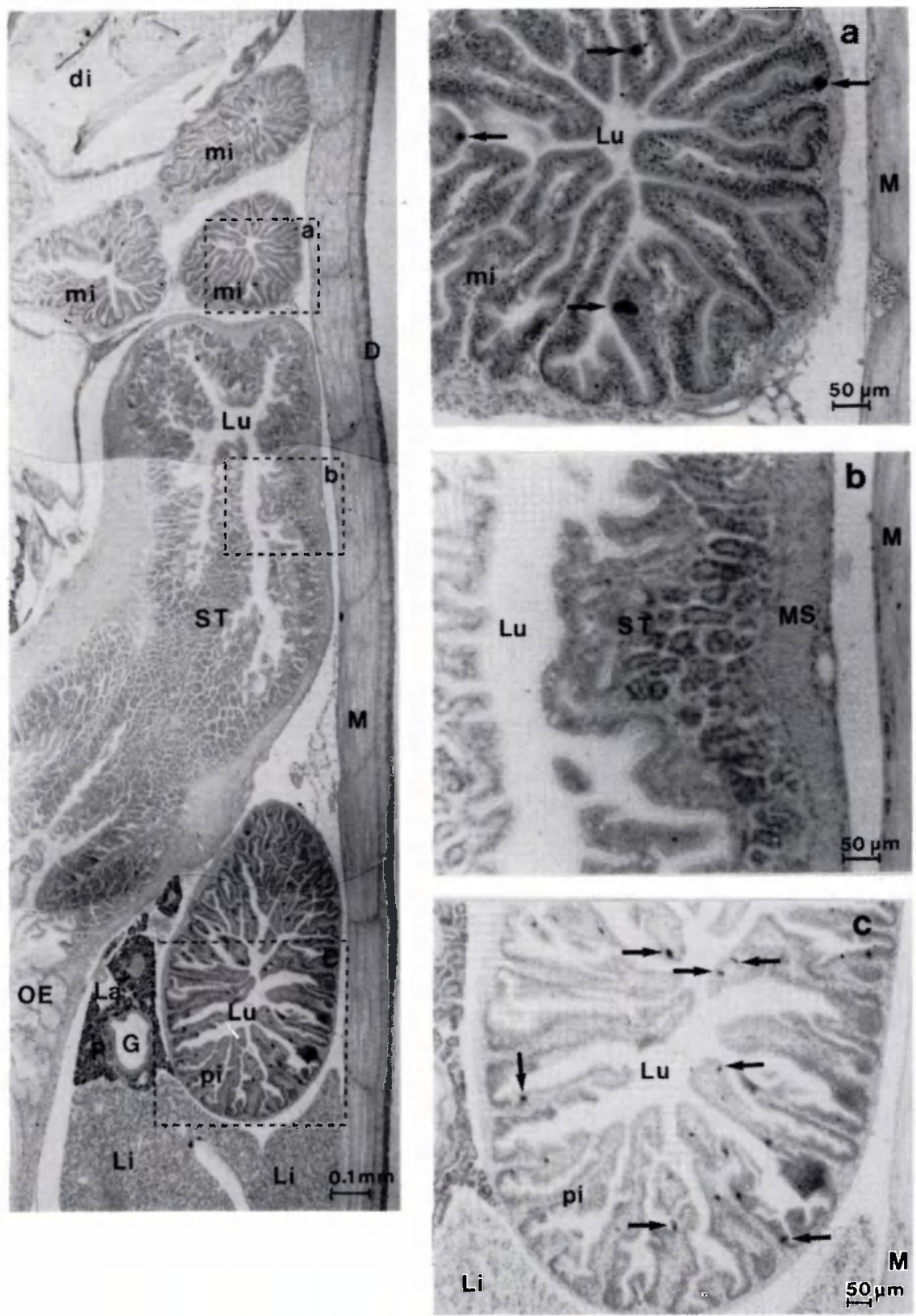

Fig. 3. An overview of a sagittal section of the digestive tract of young Clarias gariepinus. C-t-gastrinimmunoreactive cells can be distinguished in the anterior (a) and middle part (c) of the intestine but not in the stomach (b). $\mathrm{OE}=$ oesophagus, $\mathrm{P}=$ pancreas, $\mathrm{G}=$ gall bladder, $\mathrm{Li}=$ liver, $\mathrm{ST}=$ stomach, $\mathbf{M}=$ muscle, $\mathrm{D}=$ dermis, $\mathrm{pi}=$ anterior intestine, $\mathrm{mi}=$ middle intestine, $\mathrm{di}=$ posterior intestine, $\mathrm{La}$ = islet of Langerhans, $\mathrm{Lu}=$ lumen, $\mathrm{MS}=$ muscular layer of the stomach. Black arrows: C-t-gastrinimmunoreactive cells. Magnification: overview $40 \times$; selected parts of the gut and stomach $120 \times$. 


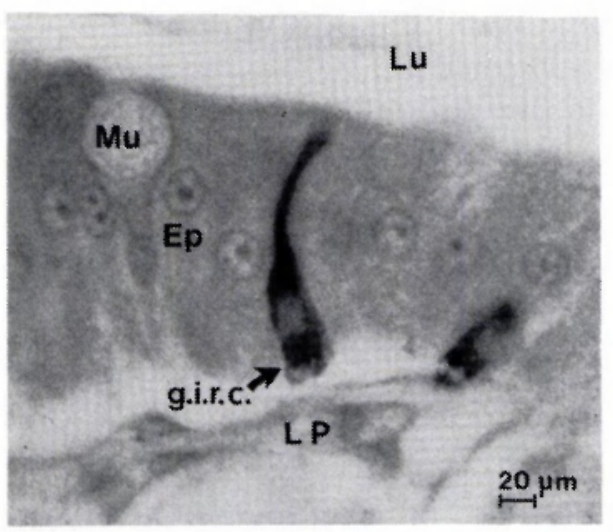

Fig. 4. Clarias gariepinus. C-t-gastrin-immunoreactive cell in the epithelium of the anterior part of the gut. $\mathrm{Ep}=$ epithelial cell, g.i.r.c. $=$ C-t-gastrin-immunoreactive cell, $\mathbf{L P}=$ lamina propia, $\mathbf{L u}=$ intestinal lumen, $\mathrm{Mu}=$ mucus cell. Magnification $1000 \times$.

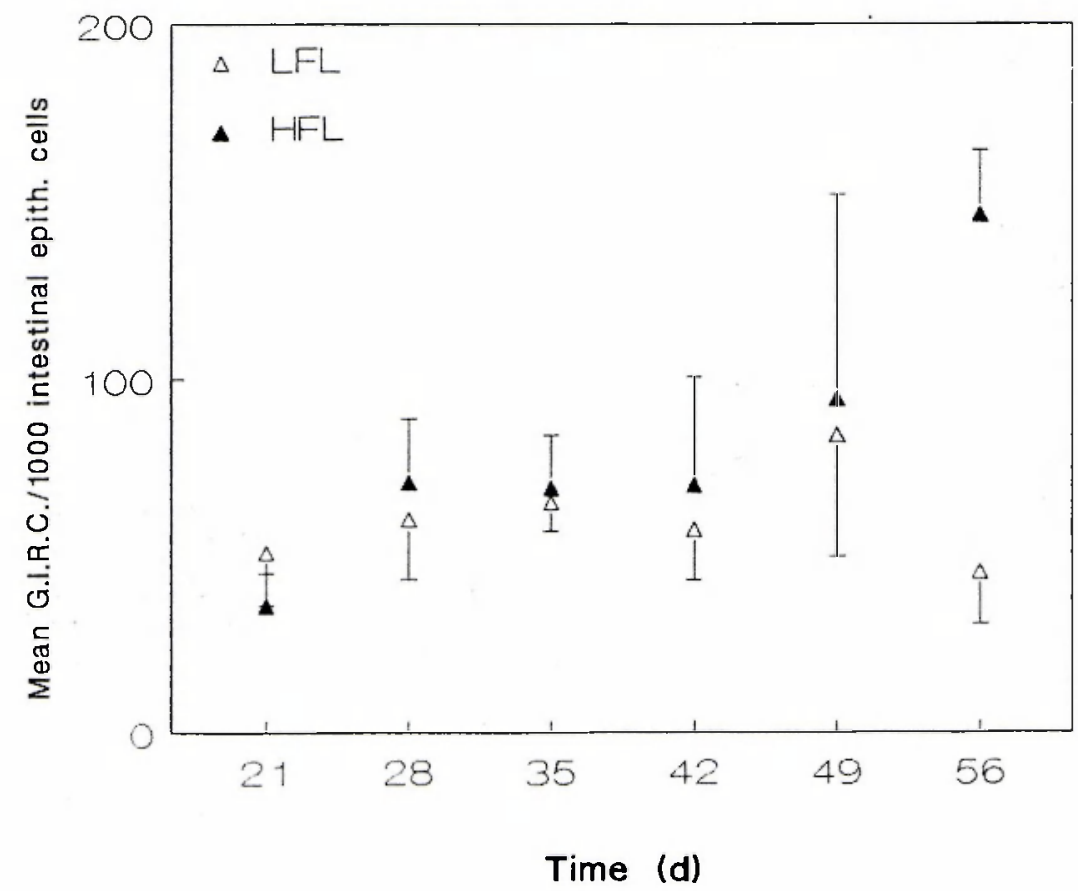

Fig. 5. Clarias gariepinus. Relationships between the number of C-t-gastrin-immunoreactive cells (GIRC) per 1000 intestinal epithelial cells and time at two different feeding levels. HFL = high feeding level, $\mathrm{LFL}=$ low feeding level. 
feld,1977; Noaillac-Depeyre \& Hollande,1981; Reifel et al., 1983; Jonsson et al., 1987). In S.auratus gastrin-immunoreactive cells could also be demonstrated in the stomach, using another anti-gastrin serum (Elbal \& Agulleiro,1986). From these data it may be concluded that gastrin-producing cells present in the stomach of some teleosts do not contain exactly the same $\mathrm{C}$-terminus as found in mammalian gastrin and cholecystokinin (CCK). Probably, the immunoreactive cells described in this study contain a CCK-like peptide. The predominant localization of the C-t-gastrinreactive cells in the first flexure of the gut, is also described for the anterior part of the gut of Barbus conchonius (Rombout \& Taverne-Thiele, 1982). The presence of a CCK-like rather than a gastrin-like hormone is proposed to be more likely in the gut of this stomachless fish.

The present study also describes a significant change in the number of these CCKlike cells during the development of young fish under different feeding conditions. In the low feeding level fish (LFL) the number of CCK-like cells is hardly changed. In the high feeding level fish (HFL) the number of CCK-like cells showed an increase after sixth weeks. In spite of the low number of fish per sample per group $(n=4)$ the influence of the feeding level on the number of C-t-gastrinimmunoreactive cells was significant at the age of 8 weeks. In the present study it is still unknown whether the high number of CCK-like cells will be related to a higher amount of secreted CCK into the blood stream and hence a stronger release of digestive enzymes and bile into the gut. However, in starved and refed rats significant changes in the epithelium of the gastric crypts and plasma gastrin levels have been reported (Goodland et al., 1983).

Whether the increase in number of the hormone-producing cells in the digestive tract is an adaptation to a high feed intake, resulting into a better digestion and hence a higher body weight gain, remains to be investigated. In some gastro-enteric diseases the CCK level in the blood is lower than normal despite the increase in the number of CCK-like cells in the gut. This may be caused by an insufficient hormone release by these cells (Sundler et al., 1983). Consequently, higher numbers of detectable CCK cells are not always correlated to an increased digestive capacity and growth.

The increase of C-terminal-gastrin-immunoreactive cells may contribute to the explanation of the health problems in the HFL, which apparently results in an increased mortality between day 42 and 49. In African catfish the high level of Cterminal-gastrin-immunoreactive cells may be related to a high level of digestive hormones. This is supported by the relationship between a high specific growth rate of African catfish over the weight range $0.5-1.0 \mathrm{~g}$ and the incidence of the ruptured intestine syndrome (RIS) (Boon et al., 1987). It is suggested that a high plasma level of digestive hormones in some specimen is followed by an autodigestion of the gut mucosa inducing the first phase of the RIS. Therefore, LFL and HFL fish should be tested for the level of CCK, according to the method of Sundler et al. (1983). This could give more insight in the problems concerning the RIS of African catfish. 


\section{References}

Abad, M. E., F. M. Peeze Binkhorst, M. T. Elbal \& J. H. W. M. Rombout, 1987. A comparative immunocytochemical study of the gastro-entero-pancreatic (GEP) endocrine system in a stomachless and a stomach-containing teleost. General and Comparative Endocrinology 66: 123-136.

Boon, J. H., R. W. A. Oorschot, A. M. Henken \& J. H. van Doesem, 1987. Ruptured intestine syndrome of unknown etiology in young African catfish, Clarias gariepinus (Burchell 1822), and its relation to the feeding level. Aquaculture 63: 283-300.

Elbal, M. T. \& B. Agulleiro, 1986. An immuno-cytochemical and ultrastructural study of endocrine cells in the gut of teleost fish, Sparus auratus L. General and Comparative Endocrinology 64: 339-354.

Grube, D., 1980. Immunoreactivities of gastrin (G-)cells. II. Non-specific binding of immunoglobulines to G-cells by ionic interactions. Histochemistry 66: 149-167.

Goodland, R. A., M. Y. T. Al-mukhtar, M. A. Ghatei, S. R. Bloom \& N. A. Wright, 1983. Cell proliferation, plasma enteroglucagon and plasma gastrin levels in starved and fed rats. Virchows Archivum B 43: 55-62.

Hogendoorn, H. \& M. M. Vismans, 1980. Controlled propagation of the African catfish, Clarias lazera (V\&V). II. Artificial reproduction. Aquaculture 21: 39-53.

Hogendoorn, H., J. A. J. Jansen, W. J. Koops, M. A. M. Machiels, P. H. van Ewijk \& J. P. van Hees, 1983. Growth and production of the African catfish Clarias lazera (V\&V). II. Effects of body weight, temperature and feeding level in intensive tank culture. Aquaculture 34: 265-285.

Holmgren, S., C. Vaillant \& R. Dimaline, 1982. Vip-, substance P-, gastrin/CCK-, bombesin-, somatostatin- and glucagon-like immunoreactivities in the gut of the rainbow trout, Salmo gairdneri. Cell and Tissue Research 223: 142-153.

Jonsson, A. C., S. Holmgren \& B. Holstein, 1987. Gastrin/CCK-like immunoreactivity in endocrine cells and nerves in the gastrointestinal tract of the cod, Gactus morhua, and the effect of peptides of the gastrin/CCK family on cod gastrointestinal smooth muscle. General and Comparative Endocrinology 66: 190-202.

Langer, M., S. van Noorden, J. M. Polak \& A. G. E. Pearse, 1979. Peptide hormone-like immunoreactivity in the gastrointestinal tract and endocrine pancreas of eleven teleost species. Cell and Tissue Research 199: 439-508.

Larsson, M. T. \& J. F. Rehfeld, 1977. Evidence for a common evolutionary origin of gastrin and cholecystokinin. Nature (London) 269: 335-338.

Modlin, I. M., A. Sank \& D. Albert, 1981. Current aspects of gut hormones. Journal of Surgical Research 30: 602-618.

Noaillac-Depeyre, J. \& E. Hollande, 1981. Evidence of somatostatin, gastrin and pancreatic polypeptidelike substances in the mucosa cells of the gut in fishes with and without stomach. Cell and Tissue Research 216: 193-203.

Noorden, S. van \& S. Falkmer, 1980. Gut islet endocrinology; some evolutionary aspects. Investigative and Cell Pathology 3: 21-35.

Reifel, C. W., M. Marin-Sorensen \& I. M. Samlof, 1983. Gastrin-immunoreactive cells in gastrointestinal tracts from four species of fish. Canadian Journal of Zoology 61: 1461-1468.

Rombout, J. H. W. M., C. P. M. van der Grinten, F. M. Peeze Brinkhorst, J. J. Taverne-Tiele \& J. Schooneveld, 1986. Immunocytochemical identification and localization of peptide hormones in the gastro-entero pancreatic (GEP) endocrine system of the mouse and a stomachless fish, Barbus conchonius. Histochemistry 84: 471-483.

Rombout, J. H. W. M. \& J. J. Taverne-Thiele, 1982. An immunohistochemical and electronmicroscopical study of endocrine cells in the gut and pancreas of a stomachless fish, Barbus conchonius (Cyprinidae). Cell and Tissue Research 227: 577-593.

Romeis, B., 1968. Mikroskopische Technik. Oldenburg Verlag, München/Wien, 757 pp.

Scopsi, L., B. L. Wang \& L. I. Larsson, 1986. Non-specific immunocytochemical reaction with certain neurohormonal peptides and basic peptid sequences. Journal of Histochemistry and Cytochemistry 34: $1469-1475$.

Snedecor, G. W. \& W. H. Cochran, 1976. Statistical methods (6th edn). Iowa State University Press, Ames, IA, $507 \mathrm{pp}$. 
J. H. BOON, J. H. W. M. ROMBOUT, G. H. R. BOOMS AND M. A. M. MACHIELS

Sternberger, L. A., 1979. Immunocytochemistry. Wiley, New York, 354 pp.

Stroband, H. W. J. \& A. G. Kroon, 1981. The development of the stomach in Clarias lazera and the intestinal adsorption of protein macromolecules. Cell and Tissue Research 215: 397-415.

Sundler, H. W. J., K. Sjolund \& R. Hakansson, 1983. Gut endocrin cells; an overview. Upssala Journal of Medical Science 39: 17-35.

Uys, W., T. Hecht \& M. Walters, 1987. Changes in digestive enzyme activities of Clarias gariepinus (Pisces: Clariidae) after feeding. Aquaculture 63: 243-250. 